\title{
RELATIONSHIP BETWEEN HEARD SIZE AND MILK PRODUCTION IN GREATER GUWAHATI REGION OF ASSAM, INDIA
}

\author{
Hemen Sarma ${ }^{1}$, Dr. Jnanashree Borah ${ }^{2}$ and Tirthankar Sarma ${ }^{3}$ \\ ${ }^{I}$ Research Scholar, Department of Earth Science, University of Science \& Technology, Meghalaya \\ ${ }^{2}$ Professor, Department of Earth Science, University of Science \& Technology, Meghalaya \\ ${ }^{3}$ Research Scholar, Department of Geography, Rajiv Gandhi University, Arunachal Pradesh \\ E-mail: 78hemensarma@gmail.com Ph No. 7086413564 \\ E-mail: tirthankar389@gmail.com Ph No.9954234766
}

\begin{abstract}
The production of milk is conceived of several factors and a very complex process. "The knowledge of relative importance of the resource inputs influencing in milk production is essential for the dairy farmer for introducing desirable change in his operation at micro level and for the policy maker for formulating plans for improvements in dairy cattle productivity based on sound economic principles at the macro level" (Rao, 1985). Household samples have been selected both from the municipal wards of Guwahati Municipal Corporation area. Out of 672 dairy farming households, 201 household have been selected for the survey. Regression analysis has been used for the study of factors affecting milk production in greater Guwahati region of Assam.
\end{abstract}

Keywords: Factor, Milk Yield, Diary Farming and Assam

\section{INTRODUCTION}

Dairy farming plays an important role in livelihood of dairy farmers. All the economic impacts are interlinked in terms of social impact such as income from sale of animals, milk cash, fertilizer and biogas. Rao (1985) in his study on factors effecting in milk production found that green fodder and concentrates, are the principle factors affecting milk production in al size-groups of farms. Tumuteggereize et al. (1999) mentioned that the breed of cow reared, purchased feeds and experience in dairy farming are the major factors that affect in dairy farming. They also mentioned that lack of support service such as extension service, insurance and credit facilities hampers in milk production. Oguz, C. and Canan, S. (2016) in their study mentioned that "higher properties of lactating cows ,expense on concentrates and supplements and spending more labor hours in farm activities increase the efficiencies while availability of European crossbred animals, higher education levels, male farmers ,full-time dairy farming and being a member of farming society decreases occurrence of the inefficiencies". The variables must be logical, relevant and applicable to the phenomenal facts. Considering the facts a no of attributes pertaining to the socio-economic status of dairy farming families has been included in the present study. 


\section{OBJECTIVES}

Based on the background outlined above, the main objectives for the study are

(i) To analyze the relationship between herd size and milk production in greater Guwahati region of Assam

\section{STUDY AREA}

Assam is a northeastern state of India, bordering with Bhutan and other northern states of the country known as Seven Sisters State. Assam is located near the Himalayas and has absolutely amazing natural view. It is bordered by the states of Arunachal Pradesh, Nagaland, Manipur,

Mizoram, Tripura, Meghalaya, as well as Bangladesh, Bhutan, and West Bengal. Assam covers an area of $78,438 \mathrm{~km}^{2}(30,285 \mathrm{sq} \mathrm{mi})$. Assam has a latitudinal extension of $24^{0} \mathrm{~N}$ to $28^{0} \mathrm{~N}$ and a longitudinal extension of $89^{0} 45^{\prime} \mathrm{E}$ to $96^{\circ} 00^{\prime} \mathrm{E}$.

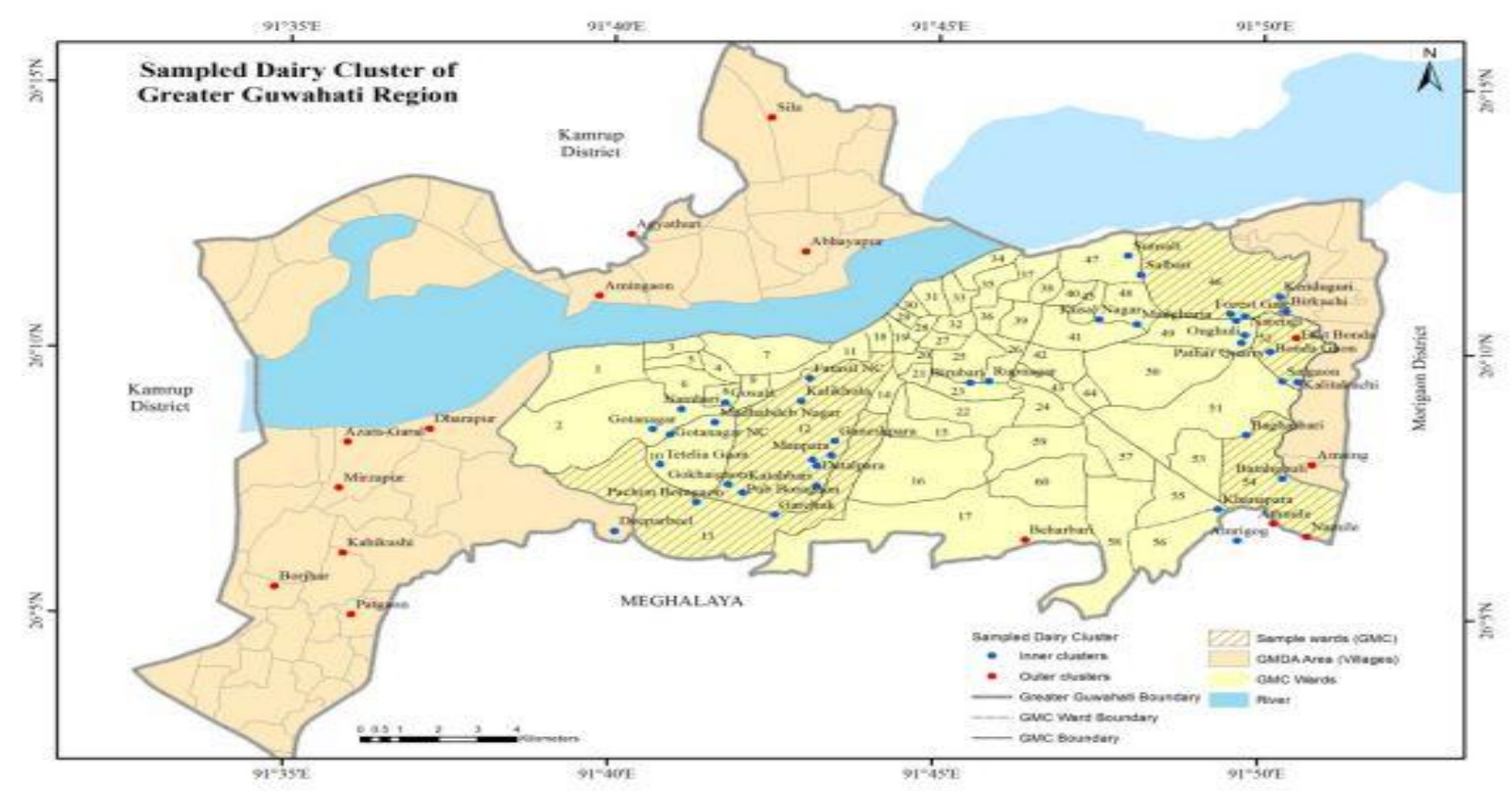

Figure 1: Study area

\section{METHODOLOGY}

The present study is based on both primary and secondary data. Household samples have been selected both from the municipal wards of Guwahati Municipal corporation area and the extended area of GMDA.Within GMC area, out of total 672 households from sampled clusters, 201 households have been selected randomly as sampled dairy households. Thus sample size stands at $30 \%$. Different types of data from various sources were acquired for this study. Secondary sources pertain to date like Census of India report, the Statistical Handbook published by the Government of Assam, Dairy co-operatives, District Animal Husbandry Department, and Town Milk Supply scheme. Some other relevant information has also been collected from various books, journals and periodicals. 


\section{RESULT AND DISCUSSION}

\section{Breeds types}

Improved breeds as an important driver to changing in milk production project. Widespread introduction of highly productive breeds of dairy cows has been major source of increased productivity in dairy sector, Cheruiyot and Otieno(2017). It means that milk production depends upon the types of breed, management types and food and fodder supply not in the number of cow reared in the dairy farm.

Table 1: Details of Breeds

\begin{tabular}{|l|l|l|l|l|l|l|l|l|l|}
\hline $\begin{array}{l}\text { Heard } \\
\text { Size }\end{array}$ & $\begin{array}{l}\text { No. } \\
\text { of } \\
\text { DHH }\end{array}$ & Mean & $\begin{array}{l}\text { No. of } \\
\text { cows }\end{array}$ & Mean & $\begin{array}{l}\text { No. of } \\
\text { Milking } \\
\text { Cow }\end{array}$ & Mean & .D & $\begin{array}{l}\text { Milk } \\
\text { Production per } \\
\text { cow(in Lt) }\end{array}$ & S.D. \\
\hline $1-10$ & 142 & 35.14 & 752 & 5.3 & 480 & 3.4 & 1.645 & 7.32 & 2.444 \\
\hline $11-20$ & 130 & 32.17 & 2130 & 16.4 & 1138 & 8.8 & 3.106 & 6.05 & 1.771 \\
\hline $21-30$ & 72 & 17.82 & 1978 & 27.5 & 1093 & 15.2 & 4.365 & 7.47 & 2.063 \\
\hline $31-40$ & 32 & 7.92 & 1158 & 36.2 & 578 & 18.1 & 5.073 & 7.43 & 1.798 \\
\hline $\begin{array}{l}\text { Above } \\
40\end{array}$ & 28 & 6.93 & 1326 & 47.4 & 518 & 18.4 & 3.644 & 8.02 & 2.998 \\
\hline Total & 404 & 100 & 7344 & 18.2 & 3803 & 9.4 & 6.377 & 7.00 & 2.269 \\
\hline
\end{tabular}

Distribution of Dairy households by herd size has explained the mean scores of Average milking cow and Milk production per cow. 142 number of household has $1-10$ herd size and 3.38 of average milking cow produced 7.32 liter of milk. 130 number of households have $11-20$ herd size have average of 8.75 milking cow which produced 6.05 liters of milk. 72 number of households have $21-30$ herd size where 15.18 number of average milking cow produced 7.47 liters of milk. 31-40 number of herd size of 32 households have 18.06 average number of milking cow and produced 7.43 liters of milk 28 numbers of households have Above 40 number of herds and average 18.36 number of milking cow which produced 8.02 liters of milk in an average. Overall 9.41 milking cow in a household produced average 7 liter of milk per day. From this it is clear that when heard size increases the production of milk also increases. But from the study it also seen that the per cow milk production is high in those dairy households where the cattle no is less in comparison to those dairy households where the cattle no is high.

Table 2: ANOVA

\begin{tabular}{|ll|l|l|l|l|l|}
\hline & & $\begin{array}{l}\text { Sum of } \\
\text { Squares }\end{array}$ & df & Mean Square & F & Sig. \\
\hline Milking Cow No. & Between Groups & 12253.424 & 4 & 3063.356 & 295.626 & .000 \\
& Within Groups & 4134.544 & 399 & 10.362 & & \\
& Total & 16387.968 & 403 & & & \\
\hline
\end{tabular}




\begin{tabular}{|ll|l|l|l|l|l|}
\hline $\begin{array}{l}\text { Milk production } \\
\text { (liter/Cow) }\end{array}$ & Between Groups & 183.355 & 4 & 45.839 & 9.668 & .000 \\
& Within Groups & 1891.701 & 399 & 4.741 & & \\
& Total & 2075.055 & 403 & & & \\
\hline
\end{tabular}

From the above ANOVA table, number of milking cow by the herd size has differed. The $\mathrm{F}$ Value 295.626 and $\mathrm{P}=0.000$ depicts that the difference of milking cow by herd size is significant at $1 \%$ level.

The increase of milking cow by herd size in sample dairy household sowing positive. From the table above it has found the $\mathrm{F}=295.626, \mathrm{P}=0.000$ reflected that the difference of milking cow by herd size in the dairy farming household is significant at $1 \%$ level.

Average per cow Milk produced in liter by herd size has shown in above table. The Fvalue $=9.668, \mathrm{P}=0.000$ depicted that the difference of milk production by herd size is significant at $1 \%$ level. It means that when number of herd size increase or decrease in a dairy farm the production of milk has impacted through it. It can be concluded that when the herd size is $1-10$ and average milk production is 7.32 liters and herd size is 11-20 the average milk production is 6.05 liters.

From the post Hoc tests, difference of milk production within group has been placed below:

Post Hoc Tests

Homogeneous Subsets

Table 3: Milking Cow in number by Herd size

Tukey HSD

\begin{tabular}{|l|l|l|l|l|l|}
\hline \multirow{2}{*}{$\begin{array}{l}\text { Herd size } \\
\text { group }\end{array}$} & \multirow{5}{|l|}{ Subset for alpha $=0.05$} \\
\cline { 3 - 6 } & $\mathrm{N}$ & 1 & 2 & 3 & 4 \\
\hline $1-10$ & 142 & 3.38 & & & \\
$11-20$ & 130 & & 8.75 & & \\
$21-30$ & 72 & & & 15.18 & \\
$31-40$ & 32 & & & & 18.06 \\
Above 40 & 28 & & & & 18.36 \\
Sig. & & 1.000 & 1.000 & 1.000 & .990 \\
\hline
\end{tabular}

Means for groups in homogeneous subsets are displayed.

Herd size and milking cow distribution has shown in above table depicted that 1-10 size of herd is differed with all remaining group of herd size with the number of milking cow which is significant at $1 \%$ level. Only 31-40 and above 40 of herd size has no significant difference in terms of milking cow in the dairy farm households. 
Table 4: Average Milk Produced per Cow

Tukey HSD

\begin{tabular}{|l|l|l|l|}
\hline \multirow{2}{*}{$\begin{array}{l}\text { Herd size } \\
\text { group }\end{array}$} & \multirow{2}{*}{$\mathrm{N}$} & \multicolumn{2}{|l|}{ Subset for alpha $=0.05$} \\
\cline { 3 - 4 } & 130 & 1 & 2 \\
\hline $11-20$ & 142 & 6.05 & \\
$1-10$ & 32 & & 7.32 \\
$31-40$ & 72 & & 7.43 \\
$21-30$ & 28 & & 7.47 \\
Above 40 & & 1.000 & 8.02 \\
Sig. & & .481 \\
\hline
\end{tabular}

Means for groups in homogeneous subsets are displayed.

Number of herd size group 11-20 has shown less production of milk comparing to the other group of herd size. The difference of milk production within the group of 11-20 herd size and other groups is significant at $1 \%$ level.

Table 5: Herd size and Net income Group

\begin{tabular}{|c|c|c|c|c|c|c|c|c|}
\hline \multirow[b]{2}{*}{$\begin{array}{l}\text { Herd } \\
\text { size }\end{array}$} & & \multicolumn{6}{|c|}{ Net income group } & \multirow[b]{2}{*}{ Total } \\
\hline & & $\begin{array}{l}\text { Below } \\
6500\end{array}$ & $\begin{array}{l}6501 \text { to } \\
12500\end{array}$ & $\begin{array}{l}12501- \\
18500\end{array}$ & $\begin{array}{l}18501- \\
24500\end{array}$ & $\begin{array}{l}24501- \\
30500\end{array}$ & $\begin{array}{l}30501 \text { and } \\
\text { above }\end{array}$ & \\
\hline $1-10$ & $\begin{array}{l}\text { Count } \\
\%\end{array}$ & $\begin{array}{l}21 \\
14.8 \%\end{array}$ & $\begin{array}{l}33 \\
23.2 \%\end{array}$ & $\begin{array}{l}20 \\
14.1 \%\end{array}$ & $\begin{array}{l}20 \\
14.1 \%\end{array}$ & $\begin{array}{l}8 \\
5.6 \%\end{array}$ & $\begin{array}{l}40 \\
28.2 \%\end{array}$ & $\begin{array}{l}142 \\
100.0 \%\end{array}$ \\
\hline $11-20$ & $\begin{array}{l}\text { Count } \\
\%\end{array}$ & $\begin{array}{l}23 \\
17.7 \%\end{array}$ & $\begin{array}{l}35 \\
26.9 \%\end{array}$ & $\begin{array}{l}13 \\
10.0 \%\end{array}$ & $\begin{array}{l}13 \\
10.0 \%\end{array}$ & $\begin{array}{l}3 \\
2.3 \%\end{array}$ & $\begin{array}{l}43 \\
33.1 \%\end{array}$ & $\left\{\begin{array}{l}130 \\
100.0 \%\end{array}\right.$ \\
\hline $21-30$ & $\begin{array}{l}\text { Count } \\
\%\end{array}$ & $\begin{array}{l}12 \\
16.7 \%\end{array}$ & $\begin{array}{l}3 \\
4.2 \%\end{array}$ & $\begin{array}{l}4 \\
5.6 \%\end{array}$ & $\begin{array}{l}6 \\
8.3 \%\end{array}$ & $\begin{array}{l}3 \\
4.2 \%\end{array}$ & $\begin{array}{l}44 \\
61.1 \%\end{array}$ & $\begin{array}{l}72 \\
100.0 \%\end{array}$ \\
\hline $31-40$ & $\begin{array}{l}\text { Count } \\
\%\end{array}$ & $\begin{array}{l}5 \\
15.6 \%\end{array}$ & $\begin{array}{l}2 \\
6.2 \%\end{array}$ & $\begin{array}{l}2 \\
6.2 \%\end{array}$ & $\begin{array}{l}1 \\
3.1 \%\end{array}$ & $\begin{array}{l}1 \\
3.1 \%\end{array}$ & $\begin{array}{l}21 \\
65.6 \%\end{array}$ & $\begin{array}{l}32 \\
100.0 \%\end{array}$ \\
\hline$>40$ & $\begin{array}{l}\text { Count } \\
\%\end{array}$ & $\mid \begin{array}{l}3 \\
10.7 \%\end{array}$ & $\begin{array}{l}1 \\
3.6 \%\end{array}$ & $\begin{array}{l}3 \\
10.7 \%\end{array}$ & $\begin{array}{l}5 \\
17.9 \%\end{array}$ & $\begin{array}{l}0 \\
.0 \%\end{array}$ & $\begin{array}{l}16 \\
57.1 \%\end{array}$ & $\begin{array}{l}28 \\
100.0 \%\end{array}$ \\
\hline Total & $\begin{array}{l}\text { Count } \\
\%\end{array}$ & $\begin{array}{l}64 \\
15.8 \%\end{array}$ & $\begin{array}{l}74 \\
18.3 \%\end{array}$ & $\begin{array}{l}42 \\
10.4 \%\end{array}$ & $\begin{array}{l}45 \\
11.1 \%\end{array}$ & $\begin{array}{l}15 \\
3.7 \%\end{array}$ & $\begin{array}{l}164 \\
40.6 \%\end{array}$ & $\mid \begin{array}{l}404 \\
100.0 \%\end{array}$ \\
\hline
\end{tabular}


Table 6:Chi-Square Tests

\begin{tabular}{|l|l|l|l|}
\hline & Value & $\mathrm{df}$ & $\begin{array}{l}\text { Asymp. Sig. (2- } \\
\text { sided) }\end{array}$ \\
\hline Pearson Chi-Square & $55.245^{\mathrm{a}}$ & 20 & .000 \\
Likelihood Ratio & 61.129 & 20 & .000 \\
Linear-by-Linear Association & 19.698 & 1 & .000 \\
$\mathrm{~N}$ of Valid Cases & 404 & & \\
\hline
\end{tabular}

The critical value of chi-square distribution with 20 d.f. The calculated Pearson's chi-square value is 55.245 at d.f. 20 (table 6.7). The tabulated value of chi-square at 0.95 probabilities is 31.416.

\section{CONCLUSION}

The calculated value is greater than the tabulated value. Hence, we say that the herd size and net income of the dairy household are not independent from each other.

From the table it is seen that dairy household where herd size is less, the income level of that dairy household is high in comparison to the dairy household where the herd size is big. Out of total 164 dairy household whose income level is above 30501, majority of the dairy household i.e. $77.43 \%$ have herd size below 30 no. This means that income level does not depend upon the herd size. It depends upon the types of breed they reared, feed supply and farm management etc.

\section{REFERENCE}

1. Cheruiyot, M.K. and Otieno, M.M., Factors Influencing Milk Production Project Among Small Scale Dairy Farmers in Bomet East Sub County, Bomet County, Kenya.

2. Gitau, K.J., 2013. Factors influencing milk production among small scale dairy farmers in Mirangine in Nyandarua county and Mauche in Nakuru county, Kenya (Doctoral dissertation, University of Nairobi).

3. Sharma, T., Saikia, S. and Medhi, B., 2020. MADAN KAMDEV TEMPLE AND ITS ARCHAEOLOGICAL REMAINS: A STUDY ON SOCIAL MILIEU LINKED ON THE NEIGHBOURING AREAS OF ASSAM, INDIA. PalArch's Journal of Archaeology of Egypt/Egyptology, 17(6), pp.6815-6826.

4. Sarma, T. and Saikia, S., 2021. Status Of Groundwater Arsenic Contamination And Human Health In Hajo Circle, Assam, India. NVEO-NATURAL VOLATILES \& ESSENTIAL OILS Journal| NVEO, pp.11297-11305.

5. Tumutegyereize, K., Hyuha, T. and Sabiiti, E.N., 1999. Factors affecting dairy production in peri-urban areas of Kampala. Uganda Journal of Agricultural Sciences, 4(1), pp.7-11.

6. Wijethilaka, D., De Silva, S., Deshapriya, R.M.C. and Gunaratne, L.H.P., 2018, May. Factors affecting sustainable dairy production: A case study from Uva Province of Sri Lanka. In IOP Conference Series: Earth and Environmental Science (Vol. 157, No. 1, p. 012063). IOP Publishing. 